\title{
A CRITICAL COMPARISON OF THE T-1824 DYE AND IODINATED ALBUMIN METHODS FOR PLASMA VOLUME MEASUREMENT ${ }^{1}$
}

\author{
By ALVIN L. SCHULTZ, JAMES F. HAMMARSTEN, BEN I. HELLER, AND \\ RICHARD V. EBERT \\ (From the Department of Medicine and the Radioisotope Unit of the Veterans Administration \\ Hospital, and the University of Minnesota Medical School, Minneapolis, Minn.)
}

(Submitted for publication August 1, 1952; accepted November 3, 1952)

The T-1824 dye method for plasma volume measurement has been subjected to much criticism. The validity of its use as a tagged protein dilution method has been questioned. One of the major criticisms has been that part of the injected dye is rapidly removed from the plasma before binding with protein occurs. This objection does not apply to the use of human serum albumin tagged with radioactive iodine before injection. Comparison of the two methods has given conflicting results (1-3). The present study was undertaken to clarify the relationship between the dye and the iodinated albumin methods for the measurement of the plasma volume.

\section{METHODS}

A modification of the T-1824 dye method described by Gibson and Evelyn (4) was used in the present study. Two cc. of an aqueous solution containing $10 \mathrm{mg}$. of T-1824 dye ${ }^{2}$ was measured in a calibrated syringe and injected intravenously. Blood samples were then drawn at 10minute intervals for 1 hour by interrupting a continuous, slow, intravenous infusion of isotonic saline. The blood samples were collected in $4 \mathrm{cc}$. hematocrit tubes containing $1.25 \mathrm{mg}$. of heparin. The plasma was separated by centrifugation for 30 minutes at 3500 r.p.m. The plàsma containing dye was compared with a blank plasma sample drawn just prior to the dye injection. An Evelyn colorimeter with a 620 millimicra filter was used. The optical densities were plotted against time on semilogarithmic paper and extrapolated to zero time $\left(C_{0}\right)$. The optical density of a $1: 1000$ dilution of $\mathrm{T}-1824$ dye in plasma was determined $(\mathrm{K})$. The $\mathrm{K}$ factor of the dye was determined individually in the plasma of each of 21 normal subjects. The mean value for the individual $K$ factors was 0.351 (S.D. 0.009). This mean $K$ was then used

1 Published with the approval of the Chief Medical Director. The statements and conclusions published by the authors are the result of their own study and do not necessarily reflect the opinion or policy of the Veterans Administration.

2 The T-1824 dye (lot 027021) used in this study was supplied by William $R$. Warner, Division of WarnerHudnut, Inc., New York, N. Y. in the calculation of the plasma volume in 13 patients in whom an individual $\mathrm{K}$ had not been determined. An individual $\mathrm{K}$ factor was determined in 15 patients and utilized in the calculation of the plasma volume. The $\mathrm{K}$ factor determined with plasma containing $1 \mathrm{gm}$. per cent of polyvinylpyrrolidone (PVP) did not differ significantly from that using plasma alone. A microadapter (5) for the Evelyn macrocolorimeter was used in all colorimetric measurements so that a 1 cc. plasma sample could be utilized. The calculation of the plasma volume was based on the following equation (6) :

$$
\text { Plasma volume (cc.) }=\frac{\mathrm{K} \times 1000 \times \mathrm{cc} \text {. of dye injected }}{\mathrm{C}_{0}}
$$

The $I^{132}$ tagged human serum albumin used in this study was supplied by Abbott Laboratories, Chicago, Ill. The solution contained $5 \mathrm{mg}$. of albumin tagged with 250 to 500 microcuries of $I^{131}$ per cc. The ionic (free) radioactive iodide was less than 1 per cent. The iodinated albumin was diluted with isotonic saline to yield a concentration of approximately 5 microcuries per cc. Ten cc. of this dilution was measured in a calibrated syringe and injected intravenously immediately following the injection of the T-1824 dye. The injected dose contained approximately 50 microcuries of $I^{131}$ tagged albumin. Blood samples were obtained from the patient for determination of radioactivity simultaneously with the blood samples for determination of dye concentration. The plasma was separated by centrifugation. Five cc. aliquots of each plasma sample were counted with a Geiger counter and the counts per minute plotted against time. By extrapolation the counts per minute at zero time were determined (E). One cc. of the iodinated albumin solution containing approximately 5 microcuries per cc. was diluted volumetrically to $100 \mathrm{cc}$. with human plasma. A $5 \mathrm{cc}$. aliquot of this dilution was counted with a Geiger counter. This represented the standard $(S)$ for the injected iodinated albumin. The plasma volume was then calculated from the following equation:

Plasma volume (cc.)

$$
=100 \times \text { cc. of tagged albumin injected } \times \frac{S}{E}
$$

All radioactivity measurements were made with a Tracer Lab. TGC-1 end window Geiger-Müller tube mounted in a lead chamber. The liquid plasma samples were counted in a cylindrical plastic cup with an internal diameter of $3 \mathrm{~cm}$. The surface of the plasma sample was $1.5 \mathrm{~cm}$. 
from the end window of the Geiger tube. Five cc. plasma samples were found to be an infinitely thick layer in this counting cup, and radioactivity counts could be duplicated with an error of less than 2 per cent.

The experimental group consisted of 10 normal men, 7 patients with carcinoma and 5 patients with lymphoblastoma, 2 patients with duodenal ulcer, 2 patients with recent small pneumothorax, 1 patient with hypertension, and 1 patient convalescing from infectious hepatitis.

\section{RESULTS}

\section{Comparison of the two methods}

Plasma volumes were determined simultaneously with dye and iodinated albumin in 28 subjects (Table I). The mean plasma volume with iodinated albumin was $3255 \mathrm{cc}$. and with the dye method it was $3314 \mathrm{cc}$. The mean difference of $59 \mathrm{cc}$. was not significant $(\mathrm{t}=1.49, \mathrm{p}>0.1)$. The correlation coefficient was 0.927 (Figure 1). An individual $\mathrm{K}$ factor for the dye was determined in 15 of these patients. The mean difference between the plasma volumes in this group as measured by the two methods was only $12 \mathrm{cc}$. A comparison was made of 28 plasma volumes calculated from the initial 10-minute plasma sample and the plasma volumes calculated from an extrapolation of 6 samples taken at 10-minute intervals for
1 hour (Table II). No significant difference between the volumes calculated from a single sample and multiple samples was found with either iodinated albumin or dye (iodinated albumin: $\mathrm{t}=$ $1.0, p>0.3$; dye : $t=0.7, p>0.5)$. The standard deviation of the difference in the plasma volumes as calculated with the 10-minute sample and the multiple sample method was $91 \mathrm{cc}$. for both iodinated albumin and T-1824 dye.

\section{Measurement of plasma volume change}

In 10 patients the plasma volume was determined with both methods simultaneously, before and immediately after the rapid intravenous administration of $1000 \mathrm{cc}$. of 3.5 per cent polyvinylpyrrolidone (PVP), a synthetic plasma volume expander (Table III). The increase in plasma volume as measured by the two methods was not significantly different $(t=0.4, p>0.6)$.

\section{T-1824 dye and iodinated albumin disappearance rates}

The decrease in plasma concentration of iodinated albumin and T-1824 dye during a 1-hour period after injection was compared (Table IV).

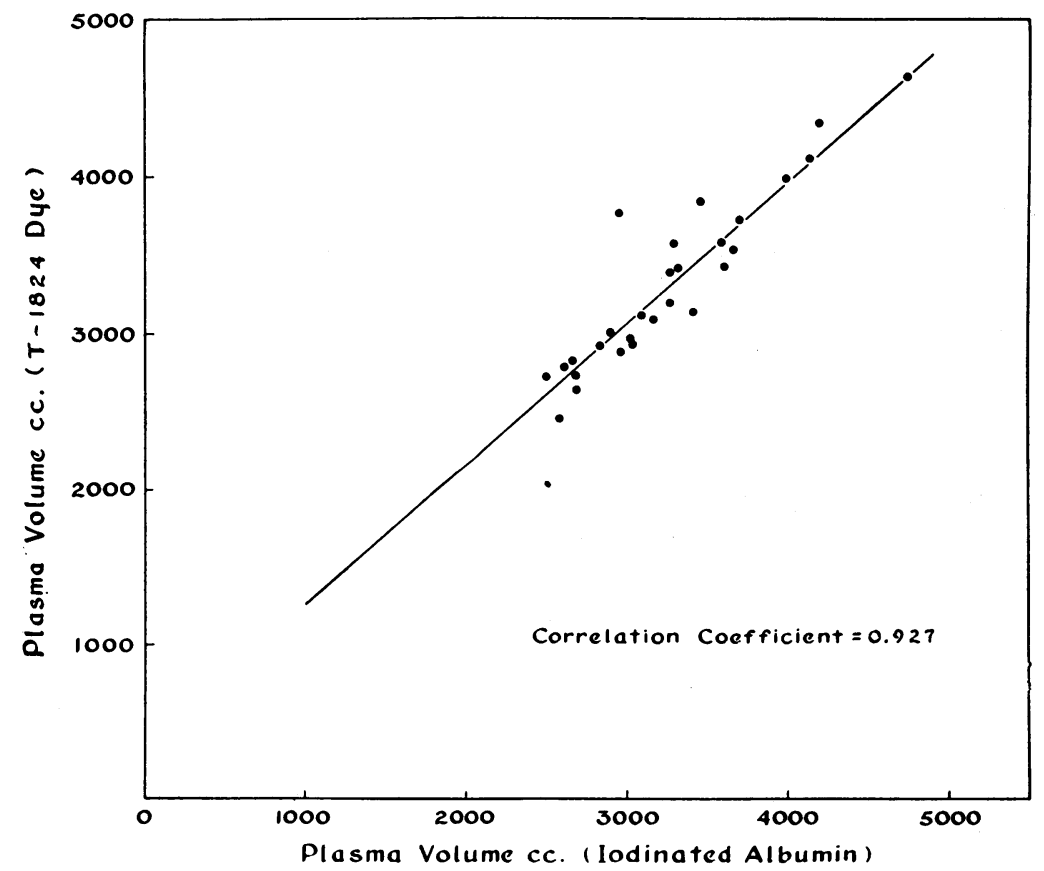

Fig. 1. Correlation Between Plasma Volumes Determined by T-1824 Dye and Iodinated Albumin 
TABLE I

Comparison of plasma volumes determined simultaneously with T-1824 dye and iodinated albumin

\begin{tabular}{|c|c|c|c|}
\hline \multicolumn{4}{|c|}{ Plasma volume } \\
\hline Patient & $\begin{array}{c}T-1824 \\
\text { dye }\end{array}$ & $\begin{array}{l}\text { Iodinated } \\
\text { albumin }\end{array}$ & Difference \\
\hline & $c c$ & $c c$ & $c c$ \\
\hline 1 & 2937 & 2821 & +116 \\
\hline 2 & 3752 & 2940 & +812 \\
\hline 3 & 2647 & 2666 & -19 \\
\hline 4 & 3114 & 3080 & +34 \\
\hline 5 & 3572 & 3287 & +285 \\
\hline 6 & 3423 & 3607 & -184 \\
\hline 7 & 3845 & 3450 & +395 \\
\hline 8 & 2724 & 2498 & +226 \\
\hline 9 & 3418 & 3312 & +106 \\
\hline 10 & 2971 & 3015 & -44 \\
\hline 11 & 2935 & 3043 & -108 \\
\hline 12 & 4101 & 4137 & -36 \\
\hline 13 & 4636 & 4747 & -111 \\
\hline $14^{*}$ & 3539 & 3651 & -112 \\
\hline $15^{*}$ & 3718 & 3701 & +17 \\
\hline $16^{*}$ & 3981 & 3982 & -1 \\
\hline $17^{*}$ & 4343 & 4180 & +163 \\
\hline $18^{*}$ & 3395 & 3260 & +135 \\
\hline $19^{*}$ & 3144 & 3401 & -257 \\
\hline $20^{*}$ & 2836 & 2658 & +178 \\
\hline $21^{*}$ & 3091 & 3154 & -63 \\
\hline $22 *$ & 3579 & 3580 & -1 \\
\hline $23^{*}$ & 2895 & 2956 & -61 \\
\hline $24^{*}$ & 3200 & 3260 & -60 \\
\hline $25^{*}$ & 2791 & 2602 & +189 \\
\hline $26^{*}$ & 2455 & 2587 & -132 \\
\hline $27^{*}$ & 3007 & 2898 & +109 \\
\hline $28^{*}$ & 2743 & 2675 & +68 \\
\hline Mean & 3314 & 3255 & +59 \\
\hline
\end{tabular}

* Individual $\mathrm{K}$ factor determined.

The mean per cent change in 1 hour was 11.5 for iodinated albumin and 11.0 for the dye. The difference between the means was not significant.

The urinary excretion of iodinated albumin was studied in 15 subjects. Over a period of two hours the urine contained 0.87 per cent of the injected radioactivity. In 4 patients 3.6 per cent of the injected radioactivity was excreted in the urine during an 8-hour period.

\section{Thoracic duct studies}

The cervical portion of the thoracic duct was cannulated in a 27 year old man undergoing a radical neck dissection for localized lymphoblastoma. The duct was not obstructed, and there was a free flow of lymph at the rate of approximately $1 \mathrm{cc}$. per minute. Samples of lymph and plasma were obtained at 10 to 20 minute intervals over a period of 140 minutes after the intravenous injection of 350 microcuries of $I^{131}$ tagged albumin. The plasma and lymph concentrations of iodinated
TABLE II

Comparison of plasma volume calculated from 10-minute value and extrapolated value

\begin{tabular}{|c|c|c|c|c|c|c|}
\hline Patient & $\begin{array}{l}\text { Extra- } \\
\text { polated } \\
\text { value }\end{array}$ & $\begin{array}{c}\Gamma-1824 \text { dye } \\
10- \\
\text { minute } \\
\text { value }\end{array}$ & Diff. & $\begin{array}{l}\text { Iodi } \\
\text { Extra- } \\
\text { polated } \\
\text { value }\end{array}$ & $\begin{array}{l}\text { nated alb } \\
10- \\
\text { minute } \\
\text { value }\end{array}$ & Diff. \\
\hline $\begin{array}{r}1 \\
2 \\
3 \\
4 \\
5 \\
6 \\
7 \\
8 \\
9 \\
10 \\
11 \\
12 \\
13 \\
14 \\
15 \\
16 \\
17 \\
18 \\
19 \\
20 \\
21 \\
22 \\
23 \\
24 \\
25 \\
26 \\
27 \\
28\end{array}$ & $\begin{array}{c}c c . \\
2937 \\
3752 \\
2647 \\
3114 \\
3572 \\
3423 \\
3845 \\
2724 \\
3418 \\
2971 \\
2935 \\
4101 \\
4636 \\
3539 \\
3718 \\
3981 \\
4343 \\
3395 \\
3144 \\
2836 \\
3091 \\
3579 \\
2895 \\
3200 \\
2791 \\
2455 \\
3007 \\
2743\end{array}$ & $\begin{array}{c}c c . \\
2894 \\
3627 \\
2741 \\
3154 \\
3481 \\
3481 \\
3895 \\
2850 \\
3478 \\
2891 \\
3029 \\
4186 \\
4745 \\
3614 \\
3687 \\
4067 \\
4356 \\
3171 \\
3196 \\
2778 \\
3057 \\
3363 \\
2942 \\
3263 \\
2850 \\
2502 \\
3056 \\
2768\end{array}$ & $\begin{array}{l}c c \\
-43 \\
-125 \\
+94 \\
+40 \\
+91 \\
+58 \\
+50 \\
+126 \\
+60 \\
+80 \\
+94 \\
+85 \\
+109 \\
+75 \\
+31 \\
+86 \\
+13 \\
+224 \\
+52 \\
+58 \\
-34 \\
-216 \\
+47 \\
+63 \\
+59 \\
+47 \\
+49 \\
+25\end{array}$ & $\begin{array}{c}c c . \\
2821 \\
2940 \\
2666 \\
3080 \\
3287 \\
3607 \\
3450 \\
2498 \\
3312 \\
3015 \\
3043 \\
4137 \\
4747 \\
3651 \\
3701 \\
3982 \\
4180 \\
3260 \\
3401 \\
2658 \\
3154 \\
3580 \\
2956 \\
3260 \\
2602 \\
2587 \\
2898 \\
2675\end{array}$ & $\begin{array}{c}c c . \\
2747 \\
3041 \\
2778 \\
3196 \\
3542 \\
3698 \\
3607 \\
2538 \\
3259 \\
2928 \\
3129 \\
4143 \\
4718 \\
3592 \\
3655 \\
4048 \\
4301 \\
3274 \\
3348 \\
2672 \\
2983 \\
3473 \\
2892 \\
3277 \\
2610 \\
2572 \\
2940 \\
2676\end{array}$ & $\begin{array}{l}c c . \\
-\quad 74 \\
+101 \\
+112 \\
+116 \\
+255 \\
+\quad 91 \\
+157 \\
+\quad 40 \\
-53 \\
-87 \\
+\quad 86 \\
+\quad 6 \\
-\quad 29 \\
-59 \\
-46 \\
+66 \\
+121 \\
+14 \\
+\quad 53 \\
+14 \\
-171 \\
-107 \\
-64 \\
+17 \\
+\quad 8 \\
+\quad 15 \\
+42 \\
+\quad 1\end{array}$ \\
\hline lean & 3314 & 3326 & +13.5 & 3255 & 3273 & +17 \\
\hline
\end{tabular}

albumin, the ratios of these concentrations, and the per cent of the injected iodinated albumin remaining in the plasma at the various time intervals are shown in Table $\mathrm{V}$. The radioactivity of cor-

TABLE III

Measurement of plasma volume with T-1824 dye and iodinated albumin before and after $1000 \mathrm{cc}$. polyvinylpyrrolidone (PVP)

\begin{tabular}{ccccccc}
\hline \hline & \multicolumn{3}{c}{ T-1824 dye } & \multicolumn{3}{c}{ Iodinated albumin } \\
Patient & Before & After & Diff. & Before & After & Diff. \\
\hline & $c c$. & $c c$. & $c c$. & $c c$. & $c c$. & $c c$. \\
6 & 3423 & 4224 & 801 & 3607 & 4371 & 764 \\
7 & 3845 & 4403 & 558 & 3450 & 3872 & 422 \\
8 & 2724 & 3421 & 697 & 2498 & 3480 & 982 \\
9 & 3418 & 4067 & 649 & 3312 & 4085 & 773 \\
10 & 2971 & 3695 & 724 & 3015 & 3737 & 722 \\
11 & 2935 & 3686 & 751 & 3043 & 3809 & 766 \\
12 & 4101 & 4853 & 752 & 4137 & 5068 & 931 \\
13 & 4636 & 5432 & 796 & 4747 & 5604 & 857 \\
$15 *$ & 3718 & 4458 & 740 & 3701 & 4384 & 683 \\
$17^{*}$ & 4343 & 5067 & 724 & 4180 & 4722 & 542 \\
& & & & & & \\
Mean & 3611 & 4330 & 719 & 3569 & 4313 & 744 \\
S.D. & 709 & 648 & 72 & 659 & 662 & 168 \\
\hline
\end{tabular}

* Individual $\mathrm{K}$ factor determined. 
TABLE IV

Per cent change in concentration of T-1824 dye and iodinated albumin in plasma in 1 hour

\begin{tabular}{|c|c|c|c|}
\hline Patient & $\begin{array}{c}\mathrm{T}-1824 \\
\text { dye }\end{array}$ & $\begin{array}{l}\text { Iodinated } \\
\text { albumin }\end{array}$ & Difference \\
\hline & $\%$ & $\%$ & $\%$ \\
\hline 1 & 13.9 & 7.3 & +6.6 \\
\hline 2 & 2.6 & 20.0 & -17.4 \\
\hline 3 & 17.1 & 19.7 & -2.6 \\
\hline 4 & 13.3 & 18.6 & -5.3 \\
\hline 5 & 8.3 & 15.5 & -7.2 \\
\hline 6 & 10.8 & 18.3 & -7.5 \\
\hline 7 & 7.9 & 21.7 & -13.8 \\
\hline 8 & 24.1 & 19.5 & +4.6 \\
\hline 9 & 9.9 & 11.1 & -1.2 \\
\hline 10 & 9.0 & 8.9 & +0.1 \\
\hline 11 & 12.3 & 12.7 & -0.4 \\
\hline 12 & 13.2 & 11.7 & +1.5 \\
\hline 13 & 13.4 & 8.1 & +5.3 \\
\hline 14 & 11.3 & 6.1 & +5.2 \\
\hline 15 & 15.6 & 10.2 & +5.4 \\
\hline 16 & 12.9 & 8.5 & +4.4 \\
\hline 17 & 13.1 & 11.9 & +1.2 \\
\hline 18 & 5.4 & 13.4 & -8.0 \\
\hline 19 & 12.4 & 8.4 & +4.0 \\
\hline 20 & 6.0 & 7.6 & -1.6 \\
\hline 21 & 7.0 & 3.9 & +3.1 \\
\hline 22 & 5.8 & 5.5 & +0.3 \\
\hline 23 & 9.5 & 8.6 & +0.9 \\
\hline 24 & 11.4 & 7.7 & +3.7 \\
\hline 25 & 10.5 & 9.3 & +1.2 \\
\hline 26 & 13.6 & 8.6 & +5.0 \\
\hline 27 & 10.1 & 11.5 & -1.4 \\
\hline 28 & 7.9 & 8.5 & -0.6 \\
\hline Mean & 11.0 & 11.5 & -0.5 \\
\hline & & & \\
\hline
\end{tabular}

TABLE V

Studies on human thoracic duct lymph after the intravenous injection of iodinated human serum albumin !

\begin{tabular}{ccccc}
\hline $\begin{array}{c}\text { Minutes } \\
\text { after } \\
\text { injection }\end{array}$ & $\begin{array}{c}\text { I131 dose per } 100 \mathrm{cc} . \\
\text { Plasma }\end{array}$ & Lymph & $\begin{array}{c}\text { Plasma/ } \\
\text { lymph } \\
\text { ratio }\end{array}$ & $\begin{array}{c}\text { Dose } \\
\text { in } \\
\text { plasma }\end{array}$ \\
\hline & $\%$ & $\%$ & & $\%$ \\
10 & 2.80 & 0.07 & 40.0 & 98.3 \\
20 & 2.65 & 0.10 & 26.5 & 91.3 \\
30 & 2.57 & 0.18 & 14.3 & 90.2 \\
45 & 2.56 & 0.35 & 7.3 & 89.9 \\
65 & 2.60 & 0.87 & 3.0 & 91.3 \\
85 & 2.43 & 0.90 & 2.7 & 85.0 \\
105 & 2.49 & 1.00 & 2.5 & 87.4 \\
135 & 2.27 & 1.08 & 2.1 & 79.4 \\
\hline
\end{tabular}

responding plasma and lymph samples is graphically illustrated in Figure 2. The plasma protein concentration was $8 \mathrm{gm}$. per $100 \mathrm{cc}$. with $5.3 \mathrm{gm}$. albumin; the lymph protein concentration was 5.7 gm. per $100 \mathrm{cc}$. with $4.2 \mathrm{gm}$. albumin. During the 6-hour period following the injection of the iodinated albumin, 4.1 per cent of the injected radioactivity was excreted in the urine. One hour after intravenous injection, approximately 10 per cent of the iodinated albumin had disappeared from the plasma. The plasma volume was $3512 \mathrm{cc}$. in this patient as measured by the iodinated albumin method.

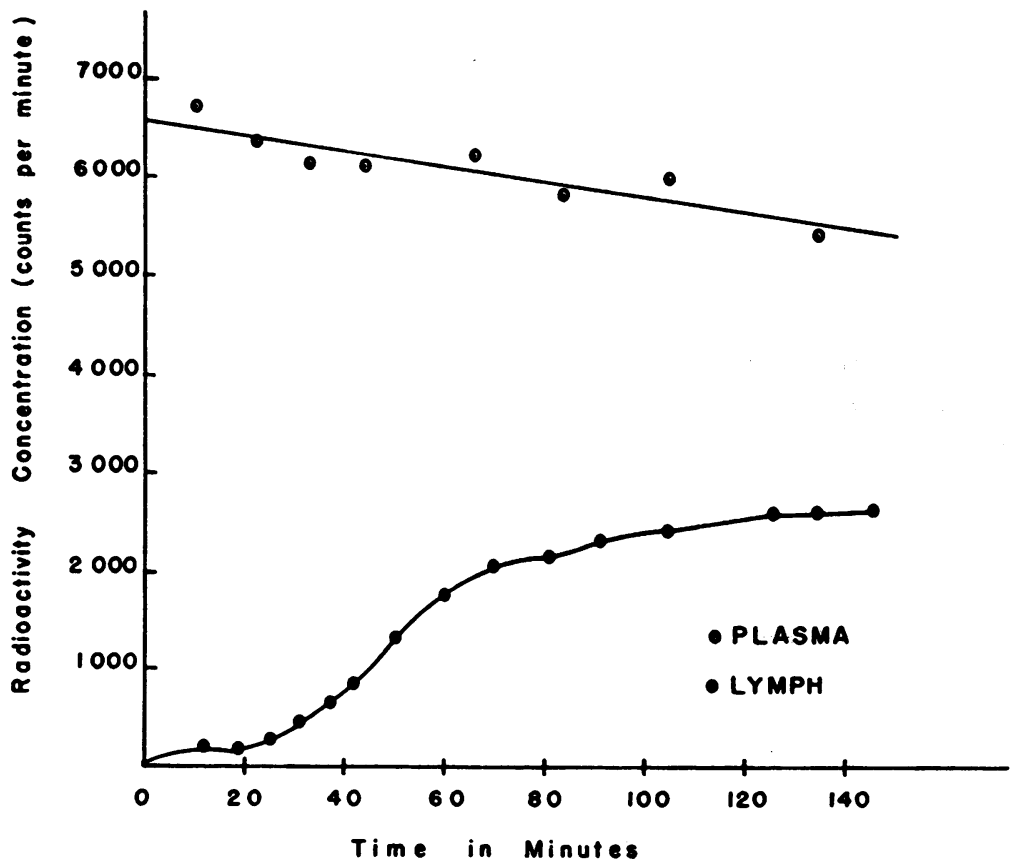

Fig. 2. Radioactivity Concentration in 5 cc. Samples of Plasma and Thoracic Duct Lymph Following Intravenous Injection of I $^{131}$ Tageed Serum Albumin 


\section{DISCUSSION}

Sterling (7), and Fine and Seligman (8) have established the reliability of the combination of $\mathrm{I}^{131}$ to albumin by in vitro and in vivo studies. Human serum albumin tagged with $\mathrm{I}^{181}$ would appear to fulfill all the desired requirements for plasma volume measurement based on the tagged protein dilution principle. Therefore, a careful comparison of the T-1824 dye and the iodinated albumin methods should be a logical and reliable experiment to study the validity of the dye method. Storaasli and his co-workers (1) and Aust and his co-workers (2) have reported that plasma volumes measured with T-1824 dye are greater than those determined simultaneously with iodinated albumin. These authors suggested that a certain amount of dye escapes from the vascular system during the first few minutes after injection. Crispell and his co-workers (3), however, found no significant difference in plasma volumes as measured by the two methods. In the present study, the T-1824 dye and the iodinated albumin methods of plasma volume measurement did not give significantly different results. This is to be expected since several investigators (9-11) have demonstrated that the intravenous injection of $\mathrm{T}-1824$ dye is followed by a rapid combination with plasma albumin. It is very unlikely that any dye is lost before binding since the dye is bound to protein very rapidly. An error in the determination of the $\mathrm{K}$ factor in the dye method will introduce a systematic error in the calculation of the plasma volume. Such an error may account for the reported discrepancy between the two methods. From the results of the present study, the concept that there is a rapid loss of $\mathrm{T}-1824$ dye from the circulation after injection and before binding to plasma protein appears untenable.

Studies on the rate of disappearance of iodinated albumin in the thoracic duct lymph of a human subject revealed that very little iodinated albumin appeared in the thoracic duct lymph during the first 30 minutes after intravenous injection. In experimental animals a somewhat larger amount of tagged protein appears in the thoracic duct lymph during the first hour after injection (1217). From the present study it would seem that in the human the amount of tagged albumin appearing in thoracic duct lymph during the period of determination of the plasma volume is small and does not significantly influence the measurement of plasma volume.

Blood volume measurements with tagged erythrocytes have been reported to result in lower values when compared with blood volumes determined by tagged plasma protein methods (18-24). This discrepancy has been attributed to the fact that the total body hematocrit is lower than the venous hematocrit. Gibson and his associates (23) studied the hematocrit of the small blood vessels using $I^{131}$ tagged albumin and erythrocytes tagged with $\mathrm{Fe}^{59}$. The hematocrit of the blood in the small vessels was found to be much lower than the hematocrit of arterial blood in all organs except the spleen. These studies assume a rigid boundary to the vascular system. The tagged protein methods measure a rapidly exchangeable pool of albumin. The anatomic limits of this albumin pool may not be identical with the anatomic limits of distribution of the erythrocytes. In a strict sense the tagged protein methods should be used as a measure of this pool of albumin. Making the assumption that all the albumin in the pool is contained in the plasma volume and that the concentration of the albumin is constant throughout the plasma, one can calculate the plasma volume. Unfortunately these assumptions are not entirely correct. Determination of the plasma volume by methods employing tagged erythrocytes is based on the assumption that the ratio of plasma to erythrocytes is constant throughout the body. This assumption is also not entirely correct. Thus, the definition of plasma volume, like the definition of extracellular fluid, will always depend upon the method used in its measurement.

Plasma volume measurements made with T-1824 dye are as valid and reliable as those made with iodinated albumin. When carefully done the two methods give similar results. The criticisms leveled at the dye method can also be made of any tagged protein method for plasma volume measurement.

\section{SUMMARY AND CONCLUSIONS}

1. The T-1824 dye and the iodinated albumin methods for plasma volume measurement when performed simultaneously in human subjects gave values which did not differ significantly. 
2. When the plasma volume was expanded by polyvinylpyrrolidone (PVP), the plasma volume change as measured by T-1824 dye and by iodinated albumin did not differ significantly.

3. Studies of human thoracic duct lymph with iodinated albumin revealed that very little tagged albumin appeared in the lymph during the first half hour after intravenous injection.

\section{REFERENCES}

1. Storaasli, J. P., Krieger, H., Friedell, H. L., and Holden, W. D., The use of radioactive iodinated plasma protein in the study of blood volume. Surg., Gynec. \& Obst., 1950, 91, 458.

2. Aust, J. B., Chou, S. N., Marvin, J. F., Brackmey, E. L., and Moore, G. E., A rapid method for clinical total blood volume determination using radioactive iodinated human serum albumin. (RIHSA). Proc. Soc. Exper. Biol. \& Med., 1951, 77, 514.

3. Crispell, K. R., Porter, B., and Nieset, R. T., Studies of plasma volume using human serum albumin tagged with radioactive iodine ${ }^{121}$. J. Clin. Invest., 1950, 29, 513.

4. Gibson, J. G., 2d, and Evelyn, K. A., Clinical studies of the blood volume. IV. Adaption of the method to the photoelectric microcolorimeter. J. Clin. Invest., 1938, 17, 153.

5. Freier, E. F., and Larson, E. A., A microadapter for the Evelyn macrocolorimeter. J. Lab. \& Clin. Med., 1948, 33, 1594.

6. Noble, R. P., and Gregersen, M. I., Blood volume in clinical shock. I. Mixing time and disappearance rate of T-1824 in normal subjects and in patients in shock; determination of plasma volume in man from 10-minute sample. J. Clin. Invest., 1946, 25, 158.

7. Sterling, K., The turnover rate of serum albumin in man as measured by $\mathrm{I}^{131}$-tagged albumin. J. Clin. Invest., 1951, 30, 1228.

8. Fine, J., and Seligman, A. M., Traumatic shock: IV. A study of the problem of the "lost plasma" in hemorrhagic shock by the use of radioactive plasma protein. J. Clin. Invest., 1943, 22, 285.

9. Rawson, R. A., The binding of T-1824 and structurally related diazo dyes by the plasma proteins. Am. J. Physiol., 1942, 138, 708.

10. Gregersen, M. I., and Rawson, R. A., The disappearance of T-1824 and structurally related dyes from the blood stream. Am. J. Physiol., 1942, 138, 698.

11. Barnes, D. W. H., Loutit, J. F., and Reeve, E. B., Observations on the estimate of the circulating red blood cell volume in man given by T-1824 and the hæmatocrit, with special reference to uncorrected dye loss from the circulation. Clin. Science, 1948, $7,155$.

12. Krieger, H., Holden, W. D., Hubay, C. A., Scott, M. W., Storaasli, J. P., and Friedell, H. L., Appearance of protein tagged with radioactive iodine in thoracic duct lymph. Proc. Soc. Exper. Biol. \& Med., 1950, 73, 124.

13. Courtice, F. C., The blood volume of normal animals. J. Physiol., 1943, 102, 290.

14. Cope, O., and Moore, F. D., A study of capillary permeability in experimental burns and burn shock using radioactive dyes in blood and lymph. J. Clin. Invest., 1944, 23, 241.

15. Ferrebee, J. W., Leigh, O. C., and Berliner, R. W., Passage of the blue dye T-1824 from the blood stream into the lymph. Proc. Soc. Exper. Biol. \& Med., 1941, 46, 549.

16. Miller, A. T., Jr., A re-evaluation of the T-1824 mixing curve. Am. J. Physiol., 1947, 151, 234.

17. Silver, A. F., and Reed, C. I., Vitamin D and the disappearance of T-1824 from the blood. Am. J. Physiol., 1948, 154, 19.

18. Barnes, D. W. H., Loutit, J. F., and Reeve, E. B., A comparison of estimates of circulating red blood cell volume given by the Ashby marked red cell method and the T-1824-hæmatocrit method in man. Clin. Science, 1948, 7, 135.

19. Hahn, P. F., Balfour, W. M., Ross, J. F., Bale, W. F., and Whipple, G. H., Red cell volume (circulating and total) as determined by radio iron. Science, 1941, 93, 87.

20. Hahn, P. F., Balfour, W. M., Ross, J. F., Bale, W. F., and Whipple, G. H., Red cell and plasma volumes (circulating and total) as determined by radio iron and by dye. J. Exper. Med., 1942, 75, 221.

21. Reeve, E. B., and Veall, N., A simplified method for the determination of circulating red-cell volume with radioactive phosphorus. J. Physiol., 1949, 108, 12.

22. Gibson, J. G., 2nd, Peacock, W. C., Seligman, A. M., and Sack, T., Circulating red cell volume measured simultaneously by the radioactive iron and dye methods. J. Clin. Invest., 1946, 25, 838.

23. Gibson, J. G., 2nd, Seligman, A. M., Peacock, W. C., Aub, J. C., Fine, J., and Evans, R. D., The distribution of red cells and plasma in large and minute vessels of the normal dog, determined by radioactive isotopes of iron and iodine. J. Clin. Invest., 1946, 25, 848.

24. Meneely, G. R., Wells, E. B., and Hahn, P. F., Application of the radioactive red cell method for determination of blood volume in humans. Am. J. Physiol., 1947, 148, 531. 